\title{
The Covid-19 Pandemic Impact on the Absorption of Non-Tax State Revenue Budget: A Study in Gorontalo Province National Land Agency Region
}

Muhdar HM ( $\sim$ muhdar73@gmail.com )

State Islamic Institute of Sultan Amai Gorontalo https://orcid.org/0000-0002-7248-1865

Roni Mohamad

State Islamic Institute of Sultan Amai Gorontalo

Muhtar Muhtar

Bosowa University: Universitas Bosowa

Wahyuddin Maguni

State Islamic Institute (IAIN) Kendari: IAIN Kendari

\section{St, Rahma}

State University of Gorontalo: Universitas Negeri Gorontalo

Hamdan Mohamad

State Islamic Institute of Sultan Amai Gorontalo: IAIN Sultan Amai Gorontalo

\section{Research}

Keywords: Non-Tax State Revenue Budget, Covid-19 Pandemic, Budget Absorption performance, Efficiency

Posted Date: February 23rd, 2021

DOI: https://doi.org/10.21203/rs.3.rs-218283/v1

License: (c) (1) This work is licensed under a Creative Commons Attribution 4.0 International License. Read Full License 


\section{Abstract}

Non-Tax State Revenue (PNBP) as a budget source for government was eroded by Covid-19 pandemic. The decline in the PNBP value of nationally results in low budget absorption at work unit level. This study aims to describe the impact caused by the Covid-19 Pandemic on budget absorption of PNBP in within Regional Office of the Gorontalo Province National Land Agency. This research uses descriptive quantitative research. The results showed that the Covid-19 pandemic had a negative impact in terms of budget absorption where budget absorption rate in third quarter did not reach the target of $60 \%$ so that the budget absorption performance value of all work units was below 80 , which means that budget absorption was in poor and very bad criteria less. Meanwhile, Covid-19 pandemic has also had a positive impact in terms of savings and efficiency in budget use, thereby reducing burden on the State Budget

\section{Introduction}

Since the emergence of the 2019 coronavirus disease (COVID-19) in December, it has spread from Wuhan province in China to the rest of the world (Chen T-M et al., 2020; Zala et al., 2020). The COVID-19 pandemic has resulted in more than 4.3 million confirmed cases and more than 290,000 deaths globally. This also triggers fears of an economic crisis and an impending recession (Nicola et al., 2020). This pandemic has caused many countries to experience a decline in income, including Indonesia. Increased spending to deal with the epidemic and the economy, as well as the decline in tax revenue and non-tax state revenue are the causes. State income until May 2020 was still depressed due to the Covid-19 pandemic, in which the situation of the global economic downturn and Indonesia greatly affected the performance of state revenues. Minister of Finance Sri Mulyani Indrawati said that up to the end of May 2020 , the realization of state revenues and grants had reached Rp.664.32 trillion. However, the achievement of state revenues and grants shrank by $9.02 \%$ (yoy) (Herman, 2020).

One of the sources of state revenue affected by the Covid-19 pandemic is Non-Tax State Revenue (Penerimaan Negara Bukan Pajak [PNBP]), which in its function as PNBP budgetary is one of the pillars of state revenue that has a significant contribution in supporting the state revenue and expenditure budget, through optimizing state revenue. PNBP realization up to May 31, 2020 reached IDR 136.9 trillion, a negative growth of $13.61 \%$ (yoy). According to the Minister of Finance, the lower PNBP realization was due to the negative growth of oil and gas natural resources by $24.38 \%$ due to the decrease in the average ICP (Inductively Coupled Plasma), the decrease in oil and natural gas lifting, and the depreciation of the rupiah exchange rate. Then, SDA Non-Oil and Gas grew negatively by $23.69 \%$ due to a decrease in the average Reference Coal Price (Harga Batubara Acuan [HBA]), a decrease in the volume of coal production, and a decrease in the volume of wood production (Rahayu, 2020).

In its function as regulatory, PNBP implementation is carried out by Ministries/ Institutions for the implementation of regulatory activities and public services provided to the public / interested parties. One of the services that was affected by the Covid-19 pandemic is the service carried out by the Ministry of Agrarian Affairs and Spatial Planning / National Land Agency related to land services. The imposition of 
social restrictions aimed at preventing the spread of the Covid-19 virus caused several public services to stop. This has an impact on decreasing state revenue from the public service sector.

Large-Scale Social Restrictions (Pembatasan Sosial Berskala Besar [PSBB]) are one of the health protocols that must be carried out to reduce the spread of Covid-19. However, on the other hand, PSBB has a bad impact on the economy. The Indonesian government issued a policy in the form of Large-Scale Social Restrictions, abbreviated as PSBB, in reducing the rate of transmission of the virus and also working in various ways (Pane, 2020). In addition to the policy of maintaining a physical distance (physical distancing) of at least one or two meters with sufferers, the government also fully supports the use of the state budget in dealing with and preventing the spread of Covid-19 (Yunus \& Rezki, 2020). Indonesia carried out the PSBB especially at the beginning of the Covid-19, namely in March, April and May so that the immediate socio-economic impact appeared significant. The Indonesian economy in the second quarter experienced a deep contraction. This deep contraction occurred because when the PSBB was implemented all economic activities stopped. In fact, there were massive layoffs in various companies due to the absence of production activities. This negative growth illustrates economic activity both from the demand side, whether consumption, investment, export, even government activities have decreased and from the production side, whether it is agriculture, trade, manufacturing, transportation, financial services, all have also experienced a very sharp decline. So Covid-19 has had a tremendous impact from an economic and social side, where poverty has also resulted in layoffs (Julita, 2020).

Large-Scale Social Restrictions (PSBB) have an impact on reducing non-tax state revenues from the public service sector. This also happened to the Ministry of Agrarian Affairs and Spatial

Planning/National Land Agency, where Non-Tax State Revenues decreased significantly compared to the 2019 period before the Covid-19 pandemic. Based on the report on the realization of comparative NonTax State Revenue (PNBP) for 2019 and 2020 up to the September period, the realization of Non-Tax State Revenue (PNBP) is as follows.

Table 1

Realization of Non-Tax State Revenue from the Ministry of Agrarian Affairs and Spatial Planning / BPN in 2019 and 2020

\begin{tabular}{|llllll|}
\hline Year & Reception & \multicolumn{2}{l}{$\%$} & $\begin{array}{l}\text { Increase / Decrease in } \\
\text { Realization }\end{array}$ & $\%$ \\
\cline { 2 - 4 } & Target & Realization & & & \\
\hline 2019 & $2,358,115,228,000$ & $1,528,574,733,415$ & 64.82 & $-390,651,669,620$ & -25.56 \\
\hline 2020 & $2,121,627,436,930$ & $1,137,923,063,795$ & 53.63 & & \\
\hline
\end{tabular}

Source: Report of Agrarian Financial Ministry and Spatial Planning / BPN in 2019 and 2020 (processed)

Based on table 1, the realization of PNBP revenue from the Ministry of Agrarian and Spatial Planning / National Land Agency decreased by $25.56 \%$ compared to the same period in 2019 . This decrease was due to the Covid-19 pandemic, which required large-scale social restrictions to reduce the spread. Covid19 virus. 
PNBP funding sources, which are contributions from the community, have funded $1 / 3$ of the funds from the Ministry of Agrarian Affairs and Spatial Planning / National Land Agency (Dinarjito, 2017). In terms of the PNBP expenditure budget, the realization of PNBP budget absorption has also decreased compared to 2019 as in table 2 .

Table 2. Realization of the Ministry of Agrarian Affairs PNBP Budget and Spatial Planning / BPN in 2019 and 2020

\begin{tabular}{|clllll|}
\hline Year & expenditure & & $\%$ & $\begin{array}{l}\text { Increase / Decrease in } \\
\text { Realization }\end{array}$ & $\%$ \\
\cline { 2 - 5 } & Ceiling & Realization & & & \\
\hline 2019 & $2,017,131,736,000$ & $735,040,510,614$ & 36.44 & $-195,080,836,907$ & -26.54 \\
\hline 2020 & $1,814,350,994,000$ & $539,959,673,707$ & 29.76 & & \\
\hline
\end{tabular}

Source: Report of Agrarian Financial Ministry and Spatial Planning / BPN in 2019 and 2020 (processed)

The decline in PNBP budget realization by $26.54 \%$ was partly due to the decline in Non-Tax State Revenues due to the Covid-19 pandemic. The decline in realized PNBP revenues is directly proportional to the allocation of PNBP expenditure budgets. In the APBN posture, if state revenue from PNBP is achieved, then the PNBP budget allocation can also be fulfilled according to the ceiling stated in the budget document.

Ministry of Agrarian Affairs and Spatial Planning/National Land Agency in carrying out their duties and functions in the regions, they form work units at the provincial level nor Regency/city. In Gorontalo Province, 7 (seven) work units are formed including the Regional Office of the Gorontalo Province National Land Agency, the Gorontalo City Land Office, the Gorontalo Regency Land Office, the Boalemo Regency Land Office, the Pohuwato Regency Land Office, the Bone Bolango Regency Land Office and the Office Land of North Gorontalo Regency. In carrying out their duties and functions in the land sector, all work units receive PNBP budget allocations. The PNBP budget allocation is intended to finance operational activities directly related to land services, including survey, measurement and mapping services, registration and maintenance services for land data, land inspection services, land technical consideration services and land information services. In addition, the PNBP budget is also used to finance non-operational PNBP activities, including to support office operations as well as support for other technical activities. The comparison of PNBP budget realization before the Covid-19 pandemic in 2019 and during the Covid-19 pandemic in 2020 to the period of September is as follows.

Table 3. PNBP Budget Realization of Gorontalo Province BPN Regional Office in 2019 and 2020 


\begin{tabular}{|c|c|c|c|c|c|}
\hline \multirow[t]{2}{*}{ No. } & \multirow[t]{2}{*}{ Work unit } & \multicolumn{2}{|c|}{$\begin{array}{l}\text { PNBP Budget Realization } \\
\text { (Year) }\end{array}$} & \multirow[t]{2}{*}{ Difference } & \multirow[t]{2}{*}{ Information } \\
\hline & & 2019 & 2020 & & \\
\hline 1. & $\begin{array}{l}\text { BPN Regional of Gorontalo } \\
\text { Province }\end{array}$ & $47.09 \%$ & $46.31 \%$ & $-0.78 \%$ & decline \\
\hline 2. & Land Office of Gorontalo City & $51.13 \%$ & $31.45 \%$ & $-19.68 \%$ & decline \\
\hline 3. & Land Office of Gorontalo Regency & $43.77 \%$ & $39.68 \%$ & $-4.09 \%$ & decline \\
\hline 4. & Land Office of Boalemo Regency & $34.80 \%$ & $22.78 \%$ & $-12.02 \%$ & decline \\
\hline 5. & Land Office of Pohuwato Regency & $52.16 \%$ & $46.08 \%$ & $-6.08 \%$ & decline \\
\hline 6. & $\begin{array}{l}\text { Land Office of Bone Bolango } \\
\text { Regency }\end{array}$ & $44.36 \%$ & $29.29 \%$ & $-15.07 \%$ & decline \\
\hline 7. & $\begin{array}{l}\text { Land Office of Gorontalo Utara } \\
\text { Regency }\end{array}$ & $48.62 \%$ & $38.68 \%$ & $-9.94 \%$ & decline \\
\hline
\end{tabular}

Source: LK e-rekon and Online Monitoring SPAN (processed, 2020)

From table 3 , it appears that the absorption of the PNBP budget for all work units has decreased from the same period in the previous year. This shows that during the Covid-19 pandemic, the work unit experienced obstacles in budget absorption, including the minimum allocation of the maximum PNBP disbursement allocated by the Head Office, because state revenues from land services nationally decreased due to the Covid-19 pandemic.

A decrease in budget realization and a slowdown in budget absorption will have an impact on slowing economic growth. For example, the delay in budget absorption for land certificate products, which should have been completed in the middle of the year, was completed at the end of the year. This has resulted in losses for the community in the form of loss of the benefits of using the land certificate, especially to gain access to capital from financial institutions. The loss of benefits in the aggregate will affect the level of economic growth. In addition, the problem of delays and uncertainty in budget absorption causes the opportunity cost of government money which results in inoptimal placement and investment of government cash if there is excess cash due to increased state revenues. The government will not take the risk of investing if there is uncertainty about budget absorption.

Research results such as Suyitno (2020: 72) found that the spread of Covid-19 had an impact on budget absorption at the Ministry of Religion Office of Mojokerto Regency. The negative impact of Covid-19 in budget absorption can be seen from the absorption rate of the new budget up to $22.59 \%$ of the target of $40 \%$. Meanwhile, the positive impacts that arise are in terms of budget savings and efficiency of budget use. Pratiwi (2020: 30) emphasized that the Covid-19 pandemic had an impact on the economic slowdown, especially in the MSME sector. Likewise, Bahtiar \& Saragih (2020: 19) emphasized that the impact of the Covid-19 pandemic on the slowdown in the MSME sector, especially product absorption, availability of raw materials, and distribution processes. Therefore, one of the policies that can be taken 
is to contain the rate of transmission of Covid 19 in order to reduce the negative impact of the pandemic (Firano \& Fatine, 2020).

This paper is based on the argument that the Covid-19 pandemic has not only a negative impact but also a positive impact on budget absorption. Improper handling of the Covid-19 pandemic has actually caused problems for the balance between government budget and spending (Ulya, 2020). Therefore, it is important for the government to take the right steps with the revised budget savings policy. And this policy also brings budget users to spending savings in a relatively proportional amount so that the balance between budget and expenditure is maintained.

This study specifically aims to determine the extent of the impact of the Covid- 19 pandemic on the absorption of the Non-Tax State Revenue budget. This study also aims to provide information about the positive and negative impacts of budget absorption during the Covid-19 pandemic.

\section{li. Literatur Review}

\section{A. Budget and Budgeting}

Budget is a statement regarding the estimated performance to be achieved during a certain period of time expressed in financial terms, while budgeting is a process or method for preparing a budget (Mardiasmo, 2009). The budget is an operational plan expressed in units of money from an organization, where one party describes the estimated costs/expenses and the other party describes the estimated revenue/revenue to cover these expenses for a certain period which is generally one year (Halim, 2004). The public sector budget is a periodic activity and financial plan (usually in an annual period) which contains programs, activities, and the amount of funds obtained (revenue/income) and required (expenditure/expenditure) in order to achieve organizational goals. There are two approaches in public sector budgeting, namely the traditional approach and the New Public Management (NPM) approach. Traditional budgeting focuses on inputs that translate into linear budgets. This means that each budget expenditure is classified based on the type of expenditure and its purpose. Budget with the NPM approach emphasizes the concept of value for money and monitoring of output performance. This approach is intended to overcome the weaknesses of the traditional approach. The budget with the NPM approach consists of several types, one of which is performance-based budgeting. Performance-based budgeting (performance budget) is budgeting that is triggered by a mission and is outcome-oriented (Haryanto \& Arifuddin, 2007).

\section{B. Budget from Non-Tax State Revenues (PNBP)}

Non-Tax State Revenues (Penerimaan Negara Bukan Pajak [PNBP]) of target is the estimated PNBP that will be received in the planned year. The PNBP target reflects the work plan of government agency services accompanied by PNBP levies (Dinarjito, 2017). The PNBP target is structured as a share of total revenue in the APBN. PNBP targets are also used as the basis for calculating budget allocations to obtain a ceiling portion that can be included in the Budget Implementation List (DIPA) of government agencies 
from PNBP funding sources. From the number of PNBP targets that have been compiled, the ceiling for the use of part of PNBP funds is calculated based on the stipulated use permit. The ceiling for the use of PNBP is the amount or amount in the rupiah figure as part of the PNBP target in a portion / percentage based on the Decree of the Minister of Finance for PNBP services and other activities permitted in accordance with laws and regulations. The usage ceiling is broken down into types of expenditure in DIPA government agencies.

The use of Non-Tax State Revenues is the amount of budget allocated to PNBP producers to finance activities related to the types of Non-Tax State Revenues produced. The use of PNBP is based on Article 15 of Law Number 9 of 2018 concerning Non-Tax State Revenue and Article 4 paragraph (1) of Government Regulation Number 73 of 1999 concerning Procedures for the Use of Non-Tax State Revenues Sourced from Certain Activities. Based on these provisions, part of PNBP (not all PNBP generated) can be used for certain activities related to the type of PNBP by the relevant agency $(K / L)$.

\section{Budget Absorption}

Budget absorption is the achievement of an estimate to be achieved during a certain period of time at a certain time or the realization of the budget (Halim, 2014). Absorption of the budget is also called realization of budget disbursement. Because what is observed is a public sector organization or government entity, budget absorption here can be interpreted as budget disbursement or realization as stated in the Budget Realization Report (Laporan Realisasi Anggaran [LRA]) at a certain time.

The performance of public managers will be assessed based on the achievement of budget targets, how much has been achieved. Performance appraisal is carried out by analyzing the deviation of actual and budgeted performance (Mardiasmo, 2009). The ability to absorb the budget is considered good and successful if the absorption realization achievement is in accordance with the actual physical performance of the work that can be completed on the assumption that the actual physical performance of the work is relatively the same as the achievement target for the completion of the planned work.

There are two points of view regarding the low absorption of the budget, namely 1 ) the absorption of the intended budget is the budget realization at the end of the year compared to the budget, and 2) in terms of disproportionate absorption of the budget (Halim, 2014). Meanwhile, the effectiveness of budget absorption puts more emphasis on the achievement of everything that is carried out effectively, which means appropriate, fast, economical, and safe (lqbal, 2018).

\section{Impact of Corona Virus Disease on Budget Absorption}

Corona virus disease 2019, known as Covid-19, is a new type of disease with rapid transmission due to the corona virus which first appeared in Hubei Province-China, to be precise the City of Wuhan. Anyone will catch COVID-19, either with mild or moderate symptoms, however, there is no special treatment for healing except with a healthy lifestyle. The fast transmission of this virus has made many countries issue 
policies by imposing lockdowns as a way to prevent the spread of the Corona virus (Setiati and Azwar, 2020).

Since the outbreak of the pandemic in Indonesia, the government has taken measures to prevent the transmission of Covid-19 in the form of Presidential Instruction of the Republic of Indonesia for 2020 Number 4, which contains an outline for refocusing activities, reallocating budgets, and accelerating the process of procuring goods and services for handling this virus. This also affects the realization of budget absorption, especially in the realization of personnel expenditure, goods expenditure and capital expenditure. Suyitno (2020) research results found that the spread of Covid-19 had an influence on budget absorption at the Ministry of Religion Office of Mojokerto Regency. From the effect of budget absorption, it has a negative impact, which can be seen from the acquisition of the value of compliance with the absorption target in the second quarter, the percentage should be at least $40 \%$ with a good value, but the data obtained by the absorption of the budget has only reached $22.59 \%$. The acquisition of performance values in the same period as 2019 is much different from the difference of 46.84, in 2020 only 56.48 was scored, still below 60 , so it is categorized as not good. However, positive impacts were found in terms of budget savings and budget use efficiency, especially efficiency in the use of official travel expenditures, meeting package costs and office operational costs..

\section{lii. Risearch Method}

The type of data collected in this study is secondary data sourced from the 2019 and 2020 budget absorption reports. In data processing, the author uses financial ratios, namely the performance value of budget absorption and the ratio of PNBP budget absorption to the Maximum allocation of PNBP Disbursement. The performance of budget absorption is assessed based on Regulation of the Minister of Finance Number 195/PMK.05/2018 concerning monitoring and evaluation of the implementation of the expenditure budget of the State Ministries/Institutions and a letter issued by the Minister of Finance Number S-837/MK.05/2019 in the form of strategic steps in implementation 2020 budget. This regulation is followed up by the Director General of the Treasury in the form of a regulation that discusses technical instructions in assessing performance indicators for budget execution at State Ministries/Institutions because it becomes a guideline for budget execution in 2020 with the following provisions:

1. The performance value of budget absorption is calculated based on the percentage of budget absorption against the ceiling of the Budget Implementing List (Daftar Isian Pelaksana Anggaran [DIPA]).

2. The target of budget absorption for Ministries/Institutions is set proportionally.

3. For Work Unit/Echelon I/KL with a realization absorption rate above the quarterly absorption target, the performance value is given a maximum of 100 .

4. The budget absorption performance value is determined on a quarterly basis based on the average of the absorption performance value that has been achieved up to the current quarter. 
Table 4

Budget Realization Target

\begin{tabular}{|ll|}
\hline Quarterly & $\begin{array}{l}\text { Budget Realization Target } \\
\text { (Minimum cumulative) }\end{array}$ \\
\hline I & $15 \%$ \\
\hline II & $40 \%$ \\
\hline III & $60 \%$ \\
\hline IV & $90 \%$ \\
\hline
\end{tabular}

The formula used to determine the performance value of PNBP budget absorption is as follows:

$$
N K P A n=\frac{P A n}{T A n} \times 100
$$

Where:

NKPA $n=$ Value of PNBP budget absorption performance (Nilai kinerja penyerapan anggaran PNBP); PA $n$ = Absorption of Quarterly PNBP Budget-nth (Penyerapan Anggaran PNBP Triwulanan Ke-n); TA $n=$ Target of Quarterly PNBP Budget Absorption - nth (Target Penyerapan Anggaran PNBP Triwulanan Ke-n)

To assess the criteria for budget absorption, the following criteria are used. (Suyitno, 69).

Table 5

Criteria for Budget Absorption Value

\begin{tabular}{|ll|}
\hline Budget Absorption Performance Value & Criteria \\
\hline More than 100 & Very good \\
\hline $91-100$ & Good \\
\hline $81-90$ & Pretty good \\
\hline $61-80$ & Not good \\
\hline 60 to below & Very less \\
\hline
\end{tabular}

Based on the analysis of the budget absorption performance value described above, it can be explained as follows:

1. If the budget absorption performance value is more than 100 , then the criteria for budget absorption are in the very good category.

2. If the performance value of budget absorption is between $91-100$, then the criteria for budget absorption are in the good category. 
3. If the performance value of budget absorption is between $81-90$, then the criteria for budget absorption are in the pretty good category.

4. If the performance value of budget absorption is between $61-80$, then the criteria for budget absorption are in not category.

5. If the budget absorption performance value is less than 60 , then the criteria for budget absorption are in the very less category.

The ratio of PNBP budget absorption to the Maximum allocation of PNBP Disbursement is a development of the ratio of the budget absorption performance value. This ratio is used to assess the extent to which the work unit can realize the PNBP budget in accordance with the maximum PNBP disbursement allocated through a Circular of the Directorate General of Treasury. In the APBN posture, although the budget with PNBP funding sources has been included in the Budget Implementation List, the utilization of the budget can only be used based on the amount of PNBP revenue that goes to the Ministry/Institution as PNBP collector. The formula used to determine the value of this ratio is as follows.

\footnotetext{
Absorption of PNBP Budget $\times 100$

Maximum Allocation of PNBP Disbursement
}

The criteria used to assess this ratio are adapted from the Budget Performance Value in accordance with the Minister of Finance Regulation Number 214/PMK.02/2017 concerning the measurement and evaluation of budget performance for the implementation of performance plans and Ministries / Institution budgets. The criteria used are as follows:

1. The value of PNBP budget absorption of more than $90 \%$ of the Maximum PNBP Disbursement is categorized as Very Good.

2. The PNBP budget absorption value of more than $80 \%-90 \%$ of the Maximum PNBP Disbursement is categorized as Good.

3. The PNBP budget absorption value of more than $60 \%-80 \%$ of the Maximum PNBP Disbursement is categorized as Sufficient.

4. The value of PNBP absorption of more than $50 \%-60 \%$ of the Maximum PNBP Disbursement is categorized as Less.

5. The value of PNBP budget absorption up to $50 \%$ of the Maximum PNBP Disbursement is categorized as Very Less.

\section{Iv. Result And Discussion}

This section presents the results and discussion of the performance value of PNBP budget absorption, the ratio of PNBP budget absorption to the maximum allocation of PNBP disbursement, the impact on budget absorption, adjustments to budget changes.. 


\section{A. Value of PNBP Budget Absorption Performance}

Based on the results of data processing, the performance value of PNBP budget absorption in the work unit within the Regional Office of the Gorontalo Province National Land Agency is as follows.

Table 6

Value of PNBP Budget Absorption Performance in Quarter III of 2019 and 2020

\begin{tabular}{|c|c|c|c|c|c|}
\hline Tahun & Work Unit & $\begin{array}{l}\text { PNBP Budget } \\
\text { Absorption }\end{array}$ & Target & Value & Criteria \\
\hline \multirow[t]{7}{*}{2019} & $\begin{array}{l}\text { BPN Regional of Gorontalo } \\
\text { Province }\end{array}$ & $47.09 \%$ & $60 \%$ & 78.48 & $\begin{array}{l}\text { Not } \\
\text { good }\end{array}$ \\
\hline & Land Office of Gorontalo City & $51.13 \%$ & $60 \%$ & 85.22 & $\begin{array}{l}\text { Pretty } \\
\text { good }\end{array}$ \\
\hline & Land Office of Gorontalo Regency & $43.77 \%$ & $60 \%$ & 72.95 & $\begin{array}{l}\text { Not } \\
\text { good }\end{array}$ \\
\hline & Land Office of Boalemo Regency & $34.80 \%$ & $60 \%$ & 58.00 & $\begin{array}{l}\text { Very } \\
\text { less }\end{array}$ \\
\hline & Land Office of Pohuwato Regency & $52.16 \%$ & $60 \%$ & 86.93 & $\begin{array}{l}\text { Pretty } \\
\text { good }\end{array}$ \\
\hline & $\begin{array}{l}\text { Land Office of Bone Bolango } \\
\text { Regency }\end{array}$ & $44.36 \%$ & $60 \%$ & 73.93 & $\begin{array}{l}\text { Not } \\
\text { good }\end{array}$ \\
\hline & $\begin{array}{l}\text { Land Office of Gorontalo Utara } \\
\text { Regency }\end{array}$ & $48.62 \%$ & $60 \%$ & 81.03 & $\begin{array}{l}\text { Pretty } \\
\text { good }\end{array}$ \\
\hline \multirow[t]{7}{*}{2020} & $\begin{array}{l}\text { BPN Regional of Gorontalo } \\
\text { Province }\end{array}$ & $46.31 \%$ & $60 \%$ & 77.18 & $\begin{array}{l}\text { Not } \\
\text { good }\end{array}$ \\
\hline & Land Office of Gorontalo City & $31.45 \%$ & $60 \%$ & 52.42 & $\begin{array}{l}\text { Very } \\
\text { less }\end{array}$ \\
\hline & Land Office of Gorontalo Regency & $39.68 \%$ & $60 \%$ & 66.13 & $\begin{array}{l}\text { Not } \\
\text { good }\end{array}$ \\
\hline & Land Office of Boalemo Regency & $22.78 \%$ & $60 \%$ & 37.97 & $\begin{array}{l}\text { Very } \\
\text { less }\end{array}$ \\
\hline & Land Office of Pohuwato Regency & $46.08 \%$ & $60 \%$ & 76.80 & $\begin{array}{l}\text { Not } \\
\text { good }\end{array}$ \\
\hline & $\begin{array}{l}\text { Land Office of Bone Bolango } \\
\text { Regency }\end{array}$ & $29.29 \%$ & $60 \%$ & 48.82 & $\begin{array}{l}\text { Very } \\
\text { less }\end{array}$ \\
\hline & $\begin{array}{l}\text { Land Office of Gorontalo Utara } \\
\text { Regency }\end{array}$ & $38.68 \%$ & $60 \%$ & 64.47 & $\begin{array}{l}\text { Not } \\
\text { good }\end{array}$ \\
\hline
\end{tabular}

Source: processed data (2020)

The budget absorption performance value is one of the indicators used to determine compliance with regulations, especially the acceleration of budget absorption. Based on the data presented in the table 
above, it appears that the performance value of PNBP budget absorption for all work units in both the third quarter of 2019 and 2020 is still below 90, meaning that the absorption of the PNBP budget is still below the target set in the third quarter of $60 \%$. In 2020, during the Covid-19 pandemic emergency, the performance value of budget absorption for all work units experienced a drastic decline compared to before the Covid-19 pandemic in 2019. This indicates that the Covid-19 pandemic has an impact on budget absorption, which results in a decrease budget absorption performance value.

In the third quarter of 2019, the performance value of the budget absorption performance of the Gorontalo Province BPN Regional Office work unit was 78.48 in the poor category where the budget absorption of $47.09 \%$ was still below the third quarter target of $60 \%$. This is because there has been no budget absorption in output related to land service operations in the form of survey, measurement and mapping services as well as land inspection services by committee B. In addition, capital expenditures for equipment and machinery up to the third quarter of 2019 have not been absorbed by the budget. The Gorontalo City Land Office work unit received a budget absorption performance score of 85.22 with good enough criteria. The absorption of the budget of $51.13 \%$ is still below the target of the third quarter, this is because the absorption of the PNBP budget has not been optimal, especially in financing operational activities for land services and capital expenditures for the procurement of data processing and communication equipment. The work unit of the Land Office of Gorontalo Regency, the absorption of the PNBP budget is $43.77 \%$ so that the performance value of budget absorption is in the not good criteria, namely 72.95. The low absorption of the PNBP budget is due to the Gorontalo Regency Land Office which has not optimally realized expenditures for goods related to land service operational activities because the physical realization has not met the target.

The work unit of the Boalemo Regency Land Office in the third quarter of 2019 obtained a budget absorption performance value of 58.00 which is in the very poor criteria. This indicates that the absorption of PNBP budget is still low at the Boalemo Regency Land Office. The cause of this nonabsorption of the budget is the absence of budget disbursement on land service outputs, including land services in the field of agricultural infrastructure, land services in the field of legal relations in agriculture and land services in the field of agrarian planning. The work unit of the Pohuwato Regency Land Office received a budget absorption performance score of 86.93 with good criteria. The absorption of the PNBP budget was $52.16 \%$, still below the third quarter target of $60 \%$. The budget absorption target has not been fulfilled because the physical realization related to land service operational activities has not been met according to the target in the Budget Implementation List (DIPA). The work unit of Bone Bolango Regency Land Office obtained a performance score in the poor category with a value of 73.93. This shows that the absorption of the PNBP budget is still below the expected target. The reason for this not being absorbed is the fact that budget realization has not been optimal for land service operations because physical targets have not been achieved. The budget absorption performance value of the work unit of North Gorontalo Regency Land Office of 81.01 is in the good enough criteria with the realization of the PNBP budget up to the third quarter of $48.62 \%$. This shows that the realization of the PNBP budget is still below the target set. The non-realization of the PNBP budget has not been achieved due to the absence of 
budget disbursement in the output of land services in the field of agrarian law relations and land services in the field of agrarian management.

The PNBP budget absorption performance value of all work units in the third quarter of 2020 experienced a significant decrease from 2019, where the percentage of budget absorption was still below the target of the third quarter of $60 \%$. The budget absorption performance value of the work unit of the Gorontalo Province BPN Regional Office was 77.18 with a budget absorption percentage of $46.31 \%$ in the poor category. This is due to the low absorption of the budget for the activities of implementing the development of the infrastructure of the infrastructure and in the activities of organizing the arrangement of legal relations for the organization. The performance value of work unit of Gorontalo City Land Office is 52.42 with the percentage of budget absorption of 31.45 , which is in the very poor category. This is due to the low absorption of budget for management support activities and activities related to land service operations.

The budget absorption performance value of the Gorontalo Regency Land Office work unit of is 66.13 with a budget absorption percentage of 39.68 which is in the poor category. The reason for the low absorption of the budget is due to the inadequate absorption of the budget for management support activities and activities related to land service operations. The budget absorption performance value of Boalemo Regency Land Office work unit of is 37.97 with a percentage of budget absorption of 22.78 which is in the very poor category. This is because the budget absorption has not been optimal for management support activities, activities related to land service operations, land acquisition activities and land control activities. The budget absorption performance value of Pohuwato Regency Land Office work unit of is 76.80 with a percentage of budget absorption of 46.08 which is in the poor category. This is because up to the third quarter there has been no disbursement of the budget for agrarian planning activities, land acquisition activities and land control activities. The budget absorption performance value of Bone Bolango Regency Land Office work unit of was 48.82 with a budget absorption percentage of 29.29 in the very poor category. This is because the budget disbursement has not been optimal for management support activities, agrarian infrastructure activities, agrarian legal relations activities, agrarian structuring activities, land acquisition activities and land control activities. The budget absorption performance value of Gorontalo Utara Regency Land Office work unit was 64.47 with a percentage of budget absorption of 38.68 which was in the poor category. This is because the disbursement of the budget has not been optimal for activities related to agrarian law, agrarian structuring and land control activities.

The low performance value of budget absorption indicates that the PNBP budget absorption is not optimal by all work units. This has an effect on the performance value of work units, especially in the assessment of budget absorption performance indicators, which are evaluated every month by the Ministry of Finance. The cause of this low absorption of the budget is largely dominated by the inadequate absorption of the budget for activities related to land services due to physical realization that has not been achieved in accordance with the targets set in the Budget Implementation List (DIPA). 


\section{B. PNBP Budget Absorption Ratio on PNBP Disbursement Maximum Allocation}

To measure of PNBP budget absorption ratio value on PNBP disbursement maximum allocation in the third quarter, the PNBP disbursements maximum total allocation up to the third quarter is determined according to a Circular of the Director General of Treasury, Ministry of Finance. Based on the disbursement maximum allocation, all work units can use the PNBP budget to finance all activities funded by the PNBP budget. According to the results of data processing, PNBP budget absorption ratio to PNBP disbursement maximum allocation in the work unit within the Regional Office of the Gorontalo Province National Land Agency is as follows. 
Table 7

PNBP Budget Absorption Ratio to PNBP Revenue Maximum Allocation for the Third Quarter of 2019 and 2020

\begin{tabular}{|c|c|c|c|c|c|}
\hline Year & Work Unit & $\begin{array}{l}\text { PNBP Disbursement } \\
\text { Maximum Allocation }\end{array}$ & $\begin{array}{l}\text { PNBP Budget } \\
\text { Absorption }\end{array}$ & $\begin{array}{l}\text { Absorption } \\
\text { Ratio }\end{array}$ & Criteria \\
\hline \multirow[t]{7}{*}{2019} & $\begin{array}{l}\text { BPN Regional Office of } \\
\text { Gorontalo Province }\end{array}$ & $3,545,980,577$ & $2,076,226,093$ & $58.55 \%$ & Less \\
\hline & $\begin{array}{l}\text { Gorontalo City Land } \\
\text { Office }\end{array}$ & $1,037,526,423$ & $651,404,759$ & $62.78 \%$ & Enough \\
\hline & $\begin{array}{l}\text { Gorontalo Regency } \\
\text { Land Office }\end{array}$ & $1,128,490,148$ & $666,653,512$ & $59.07 \%$ & Less \\
\hline & $\begin{array}{l}\text { Boalemo Regency } \\
\text { Land Office }\end{array}$ & $611,299,294$ & $264,467,003$ & $43.26 \%$ & $\begin{array}{l}\text { Very } \\
\text { less }\end{array}$ \\
\hline & $\begin{array}{l}\text { Pohuwato Regency } \\
\text { Land Office }\end{array}$ & $686,574,004$ & $413,163,034$ & $60.18 \%$ & Enough \\
\hline & $\begin{array}{l}\text { Bone Bolango } \\
\text { Regency Land Office }\end{array}$ & $728,506,143$ & $362,970,307$ & $49.82 \%$ & $\begin{array}{l}\text { Very } \\
\text { less }\end{array}$ \\
\hline & $\begin{array}{l}\text { Gorontalo Utara } \\
\text { Regency Land Office }\end{array}$ & $876,629,217$ & $512,440,759$ & $58.46 \%$ & Less \\
\hline \multirow[t]{7}{*}{2020} & $\begin{array}{l}\text { BPN Regional Office of } \\
\text { Gorontalo Province }\end{array}$ & $5,059,253,000$ & $3,045,237,412$ & $60.19 \%$ & Enough \\
\hline & $\begin{array}{l}\text { Gorontalo City Land } \\
\text { Office }\end{array}$ & $464,973,365$ & $295,240,107$ & $63.50 \%$ & Enough \\
\hline & $\begin{array}{l}\text { Gorontalo Regency } \\
\text { Land Office }\end{array}$ & $755,011,486$ & $478,044,840$ & $63.32 \%$ & Enough \\
\hline & $\begin{array}{l}\text { Boalemo Regency } \\
\text { Land Office }\end{array}$ & $408,734,320$ & $168,187,498$ & $41.15 \%$ & $\begin{array}{l}\text { Very } \\
\text { less }\end{array}$ \\
\hline & $\begin{array}{l}\text { Pohuwato Regency } \\
\text { Land Office }\end{array}$ & $445,259,938$ & $329,660,617$ & $74.04 \%$ & Enough \\
\hline & $\begin{array}{l}\text { Bone Bolango } \\
\text { Regency Land Office }\end{array}$ & $442,623,030$ & $246,738,123$ & $55.74 \%$ & Less \\
\hline & $\begin{array}{l}\text { Gorontalo Utara } \\
\text { Regency Land Office }\end{array}$ & $611,562,899$ & $303,817,780$ & $49.68 \%$ & $\begin{array}{l}\text { Very } \\
\text { less }\end{array}$ \\
\hline
\end{tabular}

Source: processed data (2020)

Table 7 shows that the PNBP budget absorption ratio on the of PNBP disbursement maximum allocation in the third quarter of both 2019 and 2020, all work units are still below $80 \%$, which means that the PNBP budget absorption ratio has not met the good category. In 2020, in the emergency situation of the Covid19 pandemic, state revenues in the PNBP sector experienced a decline so that the PNBP disbursements 
maximum allocation of experienced a slowdown and decreased from the PNBP budget ceiling stated in the budget document. This affects the work unit's performance in accelerating budget absorption.

Gorontalo Province BPN Regional Office work unit the in the third quarter of 2019 had a ratio value of $58.55 \%$ in the poor category, then increased to $60.19 \%$ in 2020 in the sufficient category. This is because the work unit has not been able to realize all the maximum allocated PNBP disbursements and there is a time constraint where the Circular of the Director General of the Treasury, which states the maximum allocation for PNBP disbursement for the last phase in the third quarter, was published at the end of September, so that the new work unit can realize its budget at the beginning of the fourth quarter. The Gorontalo City Land Office work unit has a ratio value of $62.79 \%$ with a sufficient category in 2019 , then in 2020 it increased to $63.50 \%$ in the same category. The reason why the value of the budget absorption ratio has not been achieved is the timing problem related to the maximum PNBP achievement circular letter and the non-fulfillment of PNBP budget disbursement evidence. The Gorontalo Regency Land Office Work Unit has a ratio value of $59.07 \%$ in 2019 with a poor category, then it increases to $63.32 \%$ in 2020 with a sufficient category. The value of this budget absorption ratio has not been achieved yet, in addition to the problem of timing for the maximum issuance of PNBP disbursements, this is also caused by the readiness of the work unit to meet evidence of budget disbursement. The Boalemo Regency Land Office Work Unit in 2019 obtained a budget absorption ratio value of $43.26 \%$ in the very poor category, then in 2020 it decreased to $41.15 \%$ with the same category. The reason why this ratio value has not been achieved is internal constraints in the work unit to accelerate budget absorption, both related to evidence and progress of work completion.

The Pohuwato Regency Land Office Work Unit has a budget absorption ratio value of $60.18 \%$ in 2019 in the sufficient category, then it increases to $74.04 \%$ in 2020 with the same category. The reason for this not yet reached the value of the budget absorption ratio is that the maximum amount of PNBP disbursement allocated before the third quarter is still minimal, while towards the end of September the value is large, so that the new work unit can realize its budget at the beginning of the fourth quarter. Bone Bolango Regency Land Office Work Unit has a budget absorption ratio value of 49.82 in 2019 with a very low category, then increasing to $55.74 \%$ in 2020 with a low category. The reason for this not optimal achievement of the absorption ratio of the budget is the maximum allocation value for PNBP disbursement which was still low before September, so that the work unit was not optimal in realizing its budget by the end of the third quarter. Gorontalo Utara Regency Land Office Unit has a budget absorption ratio value of $58.46 \%$ in 2019 with a low category, then decreases to $49.68 \%$ in 2020 with a very poor category. This is due to a timing problem related to the issuance of a maximum circular letter for PNBP achievement entering the end of the month and evidence of PNBP budget disbursement has not been fulfilled.

\section{The Covid-19 Impact on Budget Absorption}

The Covid-19 pandemic has had a vast impact on people's lives. From an economic perspective, the Covid-19 pandemic has resulted in a decrease in state revenues, resulting in low budget absorption. 
Graph 1, it appears that in 2020 there will be a decrease in PNBP budget absorption in all work units compared to 2019 before the emergency period of the Covid-19 pandemic. This decrease in budget realization was caused by a decrease in Non-Tax State Revenues which resulted in a decrease and a delay in the maximum allocation of PNBP disbursements allocated by the Head Office, because state revenues from land services nationally decreased due to the Covid-19 pandemic. Judging from the budget absorption performance value, where in the emergency period of the Covid-19 pandemic, budget absorption performance value for all work units experienced a quite drastic decline compared to before the Covid-19 pandemic with an achievement value below 80 , which means that budget absorption has not reached the criteria pretty good. Meanwhile, if viewed from the PNBP budget absorption ratio to PNBP disbursement maximum allocation, all work units are below $80 \%$, which means that PNBP budget absorption ratio has not met the good category. This shows that the Covid-19 pandemic has had an impact on the PNBP budget absorption in all work units within the Regional Office of Gorontalo Province National Land Agency.

\section{Positive Impact}

From the PNBP budget realization comparison on budget ceiling as well as from PNBP budget absorption comparison on maximum allocation for PNBP disbursement, it can be seen that there is a remaining budget that has not been realized. A large amount of remaining budget, assuming that output is achieved, indicates efficiency in the use of the budget. The Covid-19 Pandemic also had a positive impact on budget execution, including:

1. Cost efficiency of meeting implementation, especially in saving consumption costs and meeting package costs (fullboard/full day/half day).

2. Efficiency of spending on official trips, by reducing the intensity of meetings held online.

3. Coordination is carried out by means of an online system so that the frequency of room use decreases and the impact on electricity consumption also decreases.

4. Changes in the work patterns of civil servants. Even though the Work From Home (WFH) and Work From Office (WFO) work systems in the sense of performing tasks carried out by civil servants in turn, the resulting output targets are still achieved, this is due to the professionalism of the apparatus towards the quality of public services.

5. Optimization of land services carried out electronically during the Covid-19 pandemic, including certificate checking services, electronic mortgage rights, land registration certificates and roya have an impact on saving office stationery spending by reducing paper usage (paperless).

\section{Negative Impact}

The achievement results of budget absorption performance value with poor and very poor criteria in the third quarter of 2020 and the PNBP budget absorption ratio to the PNBP disbursement maximum allocation in the category of insufficient and very insufficient indicate a negative impact from the Covid19 pandemic on the PNBP budget absorption. The negative impact due to the Covid-19 pandemic in the 
implementation of the APBN, especially in terms of PNBP budget absorption in the work unit Scope of Regional Office of Gorontalo Province National Land Agency as follows:

1. The PNBP budget absorption did not reach the target of the third quarter of $60 \%$ so that it resulted in the achievement of low budget absorption performance values.

2. The achievement of PNBP budget absorption ratio has not been maximized because the use of the maximum allocation for PNBP disbursements has not been optimal.

3. There was a cut in the PNBP budget that was relocated to prevent the spread of Covid-19.

4. The decrease in PNBP revenues nationally from land services causes the PNBP allocated disbursement maximum amount to gradually decrease.

5. Realization of operational expenditure for land services has decreased, because physical targets have not been achieved.

6. Realization of non-operational PNBP expenditure is hampered because it is waiting for the maximum allocation of PNBP disbursement at the next stage.

7. The refocusing of activities and budgets meant that some previously planned activities could not be implemented because their budget allocations had been diverted to national priority activities.

\section{Adjustments to Budget Changes}

The Covid-19 pandemic that occurred around the world has had a very serious effect on social, economic and financial problems. The government's initial step by establishing a legal umbrella through Perppu number 1 of 2020 became the basis for policies in handling Covid-19. With extraordinary conditions and full of uncertainty, the government responded quickly through the State Budget. Significant changes have occurred in the State Budget due to the increasing need for handling the health impacts of Covid-19, social protection for affected communities, and efforts to restore the domestic economy. The State Budget posture changes were carried out through the Presidential Decree 54/2020, which was later amended again in the Presidential Decree 72/2020.

Currently, various countries are preparing to face with comprehensive actions against changes in the order of life which are called the new normal (Suyitno, 2020). The additional budget is estimated at nearly hundreds of trillions of rupiah in order to maintain the stability of public health, the country's economy and the financial administration implementation system due to the global pandemic of the Covid-19 virus (Suyitno, 2020). All these funds are needed to implement actions to fulfill the government's commitment to protect all citizens from infectious disease outbreaks. The state financial implementation system policy to maintain financial system stability in handling the Covid-19 pandemic and/or in order to overcome threats that endanger the national and/or financial system stability, the government has decided to provide an additional expenditure budget to cover financing in 2020 in in order to prevent the spread of Covid-19 amounting to IDR 405.1 trillion, which previously in the 2020 State Budget was IDR 2,540.4 trillion (Indradi et al., 2020). The budget was obtained from changes in the budget structure including refocusing the State Budget from all existing programs. 
For 2020 State Expenditures, a countercyclical policy was carried out by adjusting the ceiling to support spending on handling the Covid-19 impact on the health, social and economic side. The state budget has changed from the 2020 State Budget of IDR 2,540.4 trillion, to IDR 2,613.8 trillion in Presidential Decree $54 / 2020$, then increased to IDR 2,739.2 trillion in Presidential Decree 72/2020. Additional spending is directed at dealing with the impact of Covid-19, namely in the health sector, protecting affected communities, and economic recovery. The government has also implemented refocusing and reallocation policies, namely to increase efficiency in line with social restriction policies, for example, official travel expenditures are diverted for handling Covid-19 (Suyitno, 2020). The things that need to be considered in implementing budget recofussing are: (Krisiandi, 2020)

1. Shopping for goods that are no longer urgent due to COVID-19, including official trips, meeting packages, events that gather large numbers of people.

2. Capital expenditure procurement which is estimated to be hampered by the existence of Covid-19 or is still in the initial tender process for which there is no agreement with other parties.

3. The rest / auction optimization.

4. And other activities that are not expected to be absorbed as a direct or indirect impact of Covid- 19 .

Expenditures that are not included in spending are used to mitigate the impact of COVID-19, the budget used for stunting management, maternal and child health, and costs for eradicating HIV-AIDS, tuberculosis, dengue fever, and maintaining the system. The social assistance budget is part of the social safety net stimulus.

In responding to adjustments to these budget changes, the Ministry of Agrarian Affairs and Spatial Planning / National Land Agency is saving and refocusing activities and budgets, especially to accelerate the handling of Covid-19. The budget reallocation carried out by the Ministry of Agrarian Affairs and Spatial Planning / National Land Agency, especially the types of official travel expenditures, meeting packages and honoraria to support the government's top priority spending in handling the Covid-19 pandemic includes spending in the health sector, social safety nets and national economic recovery.

\section{Conclusion}

The Covid-19 pandemic has a domino effect on all aspects including health, social, economy and finance. The impact of this pandemic has caused a decline in state revenue, one of which is from non-tax state revenue sources. The decrease in the amount of non-tax state revenue causes a reduction in state financing from non-tax state revenue sources, which results in low budget absorption. The results showed that the Covid-19 pandemic had an impact on the absorption of the Non-Tax State Revenue budget in the work unit within the Regional Office of Gorontalo Province National Land Agency. The negative impact from the absorption side of the Non-Tax State Revenue budget can be seen from the percentage of budget absorption for all work units up to the third quarter that did not reach the target of $60 \%$. So that it has an impact on the acquisition of a budget absorption performance value below $80 \%$, which has decreased quite drastically compared to before the Covid-19 pandemic. This means that budget 
absorption is still below the sufficiently good criteria. Another negative impact that resulted from the Covid-19 pandemic was the cutting and refocusing of the budget which caused several previously planned activities to be unable to be implemented because the budget allocation had been diverted to national priority activities in the context of handling the Covid-19 pandemic.

The Covid-19 pandemic, apart from having a negative impact on the absorption performance value of the Non-Tax State Revenue, also had a positive impact in terms of budget savings and efficiency of budget use. In terms of efficient use of the budget, Padami Covid-19 has minimized the costs of conducting meetings, official travel expenditures, meeting packages and office stationery expenses, thereby reducing the burden on state budget.

\section{Declarations}

\section{Acknowledgments}

Acknowledgments to the Rector of IAIN Sultan Amai Gorontalo who assisted researchers in funding research to publication

We are authors of an article entitled "The Covid-19 Pandemic Impact on the Absorption of Non-Tax State Revenue Budget: A Study in Gorontalo Province National Land Agency Region" with below statement:

- Availability of data and materials: the source of data taken from the BPN of Gorontalo Branch. Due to the taxes' personal security, the data is not available to the public

- Competing interests: No potential conflict of interest

- Funding: Join funding/sponsor from IAIN Gorontalo, Bosowa University, IAIN Kendari, and Gorontalo State University.

- Authors' contributions: All authors have contributed to the research, data collection, and the preparation of this manuscript.

- Authors' information (optional): -

- If any of the sections are not relevant to your manuscript, please include the heading and write 'Not applicable' for that section: No

Thank you

Original Signature :

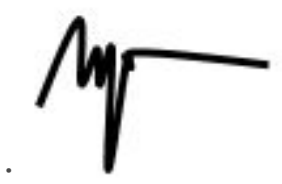

Authorized Name (Corresponding Author): Muhdar HM

Date: February 9, 2021 


\section{References}

1. Chen T-M, Rui J, Wang Q-P, Zhao Z-Y, Cui J-A, Yin L. (2020). A mathematical model for simulating the phase-based transmissibility of a novel coronavirus. Infect Dis Poverty, 9(1), 24.

2. Dinarjito, A. (2017). Pengelolaan Penerimaan Negara Bukan Pajak: Study Kasus Pada Kantor Pertanahan Wilayah Provinsi Daerah Istimewa Yogyakarta (Management of Non-Tax State Revenue: A Case Study at the Regional Land Office of the Yogyakarta Special Region Province). Jurnal Manajemen Keuangan Publik, 1(1).

3. Firano, Z., \& Fatine, A. F. (2020). The COVID-19: Macroeconomics Scenarii And Role of Containment in Morocco, One Health, journal homepage: www.elsevier.com/locate/oneh/t.

4. Halim, A. (2004). Akuntansi Sektor Publik: Akuntansi Keuangan Daerah, Edisi Revisi (Public Sector Accounting: Regional Financial Accounting, Revised Edition). Jakarta: Salemba Empat.

5. .(2014). Manajemen Keuangan Sektor Publik: Problematika Penerimaan dan Pengeluaran Pemerintah (Public Sector Financial Management: Problems of Government Revenue and Expenditure), Jakarta: Salemba Empat.

6. Haryanto, S., \& Arifuddin. (2007). Akuntansi Sektor Publik(Public sector accounting). Semarang: Badan Penerbit Universitas Diponegoro.

7. Herman. (2020). Pendapatan Negara Makin Tertekan Pandemi Covid-19 (State Income Increasingly Depressed by the Covid-19 Pandemic).https://www.beritasatu.com/faisal-malikibaskoro/ekonomi/645699/pendapatan-negara-makin-tertekan-pandemi-covid19,

8. Indradi, A. R. I. S. A. H., Arsyah, A. M., Mulyani, C. K., Athilla, K. D., Faruq, M. H. Al, Rayhan, M., Aldebarant, N. R. R., \& Dinda,S. (2020). Politik Hukum Pemerintah dalam Penanganan Pandemi Covid-19 (Government Legal Politics in Handling the Covid-19 Pandemic). Universitas Gajah Mada, 1-44. demajusticia.org

9. Ikhsan, A. (2008). Metodologi Penelitian Akuntansi Keperilakuan (Behavioral Accounting Research Methodology). Yogyakarta: Graha IImu.

10. Iqbal, M. (2018). Pengaruh Perencanaan Anggaran dan Kompetensi Sumber Daya Manusia terhadap Penyerapan Anggaran dengan Komitmen Organisasi sebagai Pemoderasi (Effect of Budget Planning and Human Resources Competence on Budget Absorption with Organizational Commitment as Moderator). Tesis, Makassar: Universitas Hasanuddin.

11. Julita, S.L. (2020). Sri Mulyani Bicara Dampak PSBB: Luar Biasa Serius! (Sri Mulyani Discusses the Impact of the PSBB: Extraordinary Serious!). Indonesia, CNBC,

https://www.cnbcindonesia.com/news/20200911180024-4-186241/sri-mulyani-bicara-dampakpsbb-luar-biasa-serius.

12. Kementerian Agraria dan Tata Ruang/Badan Pertanahan Nasional. (2020). Pedoman Pelaksanaan Anggaran, Pelaporan Keuangan dan Barang Milik Negara Tahun Anggaran 2020 (Guidelines for Budget Implementation, Financial Reporting and State Property for the 2020 Fiscal Year). Jakarta: Sekretariat Jenderal, Kementerian ATR/BPN. 
13. Kementerian Keuangan Republik Indonesia. (2010). Keputusan Menteri Keuangan Nomor 237/KMK.02/2010 tentang Persetujuan Penggunaan Sebagian Dana Penerimaan Negara Bukan Pajak pada Badan Pertanahan Nasional (Decree of the Finance Minister of Number 237/ KMK.02/2010 concerning the Approval of the Use of Part of the Non-Tax State Revenue Funds at the National Land Agency)

14. Krisiandi, E. (2020). Kebijakakan Ekonomi Jokowi Di Tengah Pandemi Covid-19: Penangguhan Cicilan Hingga Relaksasi Pajak (Jokowi's Economic Policy Amid the Covid-19 Pandemic: Postponement of Installments to Relaxation of Taxes). Kompas.Com.

15. Mardiasmo. (2009). Akuntansi Sektor Publik(Public sector accounting). Yogyakarta: Penerbit Andi.

16. Nicolaa, M., Alsafib, Z., Sohrabic, C., Kerwand, A., Al-Jabird, A., losifidisc, C., Aghae, M., \& Agha, R. (2020). The socio-economic implications of the coronavirus pandemic (COVID-19): A review. International Journal of Surgery, 78,185 - 193

17. Pane, M. D. C. (2020). Virus Corona (COVID-19) - Gejala, penyebab dan mengobati(Corona Virus (COVID-19) - Symptoms, causes and treatment). Aladokter.

18. Puspasari, R. (2020). Menjaga Ekonomi Di Tengah Pandemi Covid-19 (Maintaining the Economy Amid the Covid-19 Pandemic).https://www.kemenkeu.go.id/publikasi/siaran-pers/siaran-persmenjaga-ekonomi-di-tengah-pandemi-covid-19

19. Republik Indonesia. (2015). Peraturan Pemerintah Nomor 128 Tahun 2015 tentang Jenis dan Tarif atas Jenis Penerimaan Negara Bukan Pajak yang Berlaku pada Kementerian Agraria dan Tata Ruang/Badan Pertanahan Nasional(Government Regulation Number 128 of 2015 concerning Types and Rates of Types of Non-Tax State Revenues Applicable to the Ministry of Agrarian Affairs and Spatial Planning / National Land Agency)

20. Republik Indonesia. (2017). Peraturan Menteri Keuangan Nomor 214/PMK.02/2017 tentang Pengukuran dan Evaluasi Kinerja Anggaran atas Pelaksanaan Rencana Kinerja dan Anggaran Kementerian/Lembaga(Finance Minister Regulation of Number 214 / PMK.02 / 2017 concerning Measurement and Evaluation of Budget Performance for the Implementation of Ministry / Agency Performance Plans and Budgets.)

21. Republik Indonesia. (2018). Undang-Undang Nomor 9 Tahun 2018 tentang Penerimaan Negara Bukan Pajak(Law Number 9 of 2018 concerning Non-Tax State Revenue)

22. Republik Indonesia. (2018). Peraturan Menteri Keuangan Nomor 195/PMK.05/2018 tentang Monitoring dan Evaluasi pelaksanaan Anggaran belanja Kementerian Negara/Lembaga (Finance Minister Regulation of Number 195/PMK.05/2018 concerning Monitoring and Evaluation of State Ministries / Institution Budget implementation.)

23. Republik Indonesia. (2020). Peraturan Presiden Nomor 54 Tahun 2020 tentang Perubahan Postur dan Rincian Anggaran dan Belanja Negara Tahun Anggaran 2020(Presidential Regulation of Number 54 of 2020 concerning Posture Changes and Details of the State Budget and Expenditures for the 2020 Fiscal Year). 
24. Republik Indonesia. (2020). Peraturan Presiden Nomor 72 Tahun 2020 tentang Perubahan atas Peraturan Presiden Nomor 54 Tahun 2020 tentang Perubahan Postur dan Rincian Anggaran dan Belanja Negara Tahun Anggaran 2020 (Presidential Regulation of Number 72 of 2020 concerning Amendments to Presidential Regulation Number 54 of 2020 concerning Changes in Posture and Details of State Budget and Expenditures for the 2020 Fiscal Year).

25. Republik Indonesia. (2020). Peraturan Pemerintah Pengganti Undanbg-Undang Nomor 1 Tahun 2020 tentang Kebijakan Keuangan Negara dan Stabilitas Sistem Keuangan untuk Penanganan Pandemi Corona Virus Disease 2019 (COVID 19)dan/atau Dalam Rangka Menghadapi Ancaman yang Membahayakan Perekonomian Nasional dan/atau Stabilitas Sistem Keuangan (Government Regulation in Lieu of Law Number 1 of 2020 concerning State Financial Policy and Financial System Stability for Handling the Corona Virus Disease 2019 (COVID 19) Pandemic and / or in the Context of Facing Threats that Endanger the National Economy and / or Financial System Stability)

26. Sugiyono. (2008). Metode Penelitian Pendekatan Kuantitatif, Kualitatif, dan R\&D (Research Methods of Quantitative, Qualitative and R \& D Approaches). Bandung: Alfabeta.

27. Suyitno, Andik. (2020). Dampak Pandemi Terhadap Penyerapan Anggaran Di Kantor Kementerian Agama Kabupaten Mojekerto (The Pandemic Impact on Budget Absorption at the Office of the Religion Ministry, Mojekerto Regency). Jurnal Publik Policy, 6(2)

28. Ulya, H.N. (2020). Alternatif Strategi Penanganan Dampak Ekonomi Covid-19 Pemerintah Daerah Jawa Timur Pada Kawasan Agropolitan (Strategies Alternative for Handling the Economic Impact of Covid-19 East Java Regional Government in an Agropolitan Area). Journal of Islamic Economic and Business, 3(1), 80-109

29. Yunus, N. R., \& Rezki, A. (2020). Kebijakan Pemberlakuan Lock Down Sebagai Antisipasi Penyebaran Corona Virus Covid-19 (Lock Down Enforcement Policy in Anticipation of Corona Virus Covid-19 Spread). SALAM: Jurnal Sosial dan Budaya Syar-I, 7(3), 227- 238. https://doi.org/10.15408/sjsbs.v7i3.15083.

30. Zala, D., Mosweu, I., Critchlow, S., Romeo, R., \& McCrone, P. (2020. Costing the COVID-19 Pandemic: An Exploratory Economic Evaluation of Hypothetical Suppression Policy in the United Kingdom. Value Health, 23(11), 1432-1437

\section{Figures}




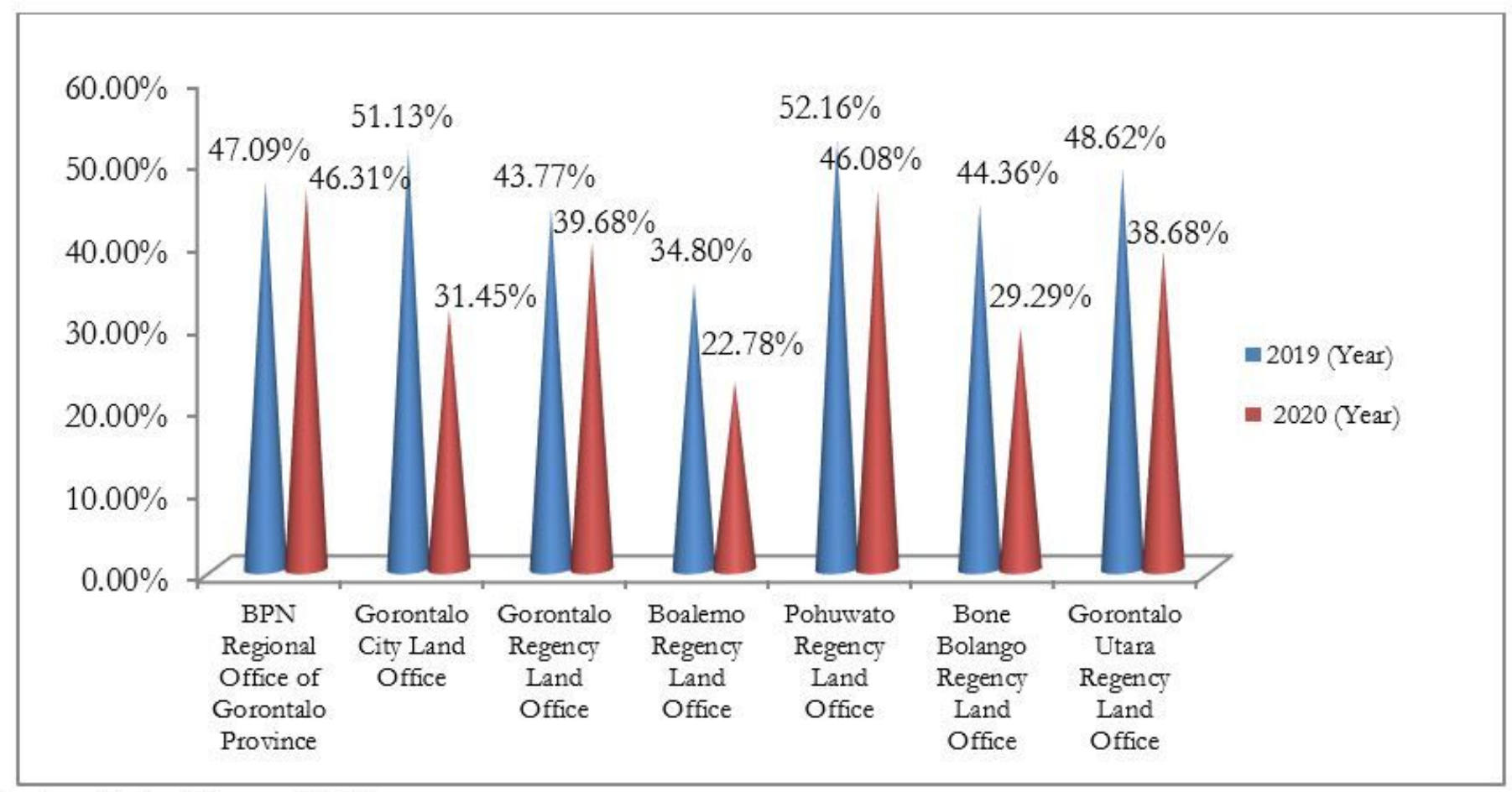

Sumber: Data of Process (2020)

Figure 1

PNBP Budget Realization Comparison for Third Quarter 2019 and 2020

\section{Supplementary Files}

This is a list of supplementary files associated with this preprint. Click to download.

- DataMaterials.docx 